\title{
Skrining pranikah untuk pencegahan thalassaemia mayor yang efektif dan efisien.
}

\author{
Danang Kastowo*1, Alif Syaiful Huda ${ }^{2}$, Andy Saputra ${ }^{3}$ dan Erna \\ Setyowati $^{4}$
}

$1 \quad$ PT. Dua Empat Tujuh

Yogyakarta, Indonesia

danang. kastowo@labs247.id

2 Universitas AMIKOM Yogyakarta

Jl. Padjajaran, Ring Road Utara, Kel. Condongcatur, Kec. Depok, Kab.

Sleman, Prop. Daerah Istimewa Yogyakarta

alifshd@students . amikom. ac.id

3 Universitas AMIKOM Yogyakarta

Jl. Padjajaran, Ring Road Utara, Kel. Condongcatur, Kec. Depok, Kab.

Sleman, Prop. Daerah Istimewa Yogyakarta

andy@students . amikom.ac.id

4 Universitas AMIKOM Yogyakarta

Jl. Padjajaran, Ring Road Utara, Kel. Condongcatur, Kec. Depok, Kab.

Sleman, Prop. Daerah Istimewa Yogyakarta

erna@students.amikom.ac.id

\begin{abstract}
Abstrak
Penyakit thalassaemia merupakan penyakit keturunan yang tidak dapat disembuhkan dan memerlukan transfusi darah secara terus-menerus bagi penderita mayor. Tindakan pencegahan utama dari thalassaemia adalah dengan cara mengidentifikasi pembawa sifat dan mencegah kelahiran bayi thalassaemia mayor lainnya. Analisis data inferensial, dengan pengambilan sampel data terhadap jumlah populasi (data penderita thalassaemia mayor) dan digunakan untuk menarik suatu kesimpulan. Metode penelitian yang digunakan adalah metode kuantitatif, yakni dengan menghitung jumlah penderita thalassaemia mayor di Indonesia, kemudian mengelompokan berdasarkan status pernikahan, usia penderita, dan layanan asuransi kesehatan yang sudah digunakan. Hasil penelitian menunjukkan penderita thalassaemia mayor pada usia siap menikah (20-30 tahun) masih sangat tinggi, sehingga kegiatan skrining pranikah perlu dilakukan untuk mencegah penurunan thalassaemia mayor pada anak.
\end{abstract}

Kata Kunci thalassaemia, bpjs, stok darah, screening, pranikah

\section{Pendahuluan}

Penyakit thalassaemia merupakan penyakit kelainan darah yang diakibatkan faktor genetika, hal ini disebabkan protein yang ada di dalam sel darah merah (hemoglobin) tidak berfungsi secara normal. Hemoglobin memiliki peranan penting dalam mengantarkan oksigen dari paru-paru ke seluruh anggota tubuh. Penyakit ini tidak dapat disembuhkan, sehingga bagi penderita thalassaemia mayor memerlukan transfusi darah secara rutin untuk menunjang kelangsungan hidupnya [1; 2]. Di Seluruh dunia, diperkirakan 320.000 bayi lahir dengan Hemoglobinopati setiap tahunnya, dan $80 \%$ terjadi di negara berpenghasilan rendah atau menengah, Indonesia merupakan salah satu negara yang termasuk golongan tersebut [1],

* Corresponding author.

(c) (i) (1) Kastowo. D, dkk.;

licensed under Creative Commons License CC-B 
dengan jumlah populasi penduduk Indonesia lebih dari 270 juta jiwa [3]. Sekitar $5 \%$ dari populasi diperkirakan membawa gen thalassaemia. Dengan angka kelahiran sekitar $20 \%$ per tahun, menurut Wahidiyat, akan ada sekitar 2.500 kasus baru thalassaemia mayor per tahun, menjadikan Indonesia hot spot untuk thalassaemia[4] . Menurut Data Bank Dunia, Indonesia dianggap sebagai negara berpenghasilan menengah yang sedang berkembang. Ini adalah negara terpadat keempat di dunia dan terbesar ke-10 di dunia ekonomi dalam hal keseimbangan daya beli [5]. Dari ulasan diatas bertujuan untuk memberikan wawasan tentang data dan praktik thalassaemia terkini dan perspektif negara berpenghasilan menengah, khususnya di Indonesia. Menurut data Kemenkes pada tahun 2019, penderita thalassaemia mayor mencapai 10.531 pasien. Persentase jumlah penderita jika dibandingkan dengan total penduduk Indonesia sekitar 0,0037\%, akan tetapi pada tahun 2019, menurut data BPJS Kesehatan penyakit thalassaemia berada di posisi nomor 5 dalam hal pembiayaan kesehatan [3]. Biaya perawatan yang mahal dan penderita thalassaemia mayor memerlukan transfusi darah secara rutin untuk menunjang kelangsungan hidupnya. Hal tersebut yang menjadikan latar belakang masalah mengapa thalassaemia di Indonesia perlu dikendalikan dan ditekan laju pertumbuhannya.

Merujuk dari penelitian yang sudah pernah dilakukan Pustika Amalia Wahidiyat dkk pada tahun 2020 yang berjudul An insight into Indonesian current thalassaemia care and challenges memberikan kesimpulan bahwa tindakan pencegahan utama adalah dengan cara mengidentifikasi thalassaemia pembawa sifat dan mencegah pernikahan diantara mereka untuk mencegah kelahiran bayi thalassaemia mayor lainnya [1]. Proses skrining pranikah sudah terdengar sukses di negara seperti Turki, Yunani, Italia dan Siprus. Mengikuti program pencegahan dengan cara skrining, tidak ada bayi thalassaemia mayor yang lahir sampai tahun 2007 di Siprus Utara. Sebuah studi dari Israel membuktikan bahwa skrining adalah solusi hemat biaya dengan setidaknya lebih murah dibandingkan dengan pengobatan [1].

Dari hasil penelitian yang sudah pernah dilakukan oleh Pustika Amalia Wahidiyat dkk sebelumnya, penelitian ini lebih memfokuskan pada upaya pengendalian resiko yang dapat dilakukan untuk menekan laju pertumbuhan thalassaemia mayor di Indonesia, diantaranya skrining thalassaemia untuk masyarakat di wilayah dengan angka penyebaran thalassaemia tinggi. Dari kegiatan ini didapatkan data terbaru terkait jumlah penderita thalassaemia mayor di suatu wilayah, sehingga dapat dijadikan sebagai tolak ukur keberhasilan dalam upaya pencegahan dan penanganan thalassaemia mayor di wilayah tersebut.

Merujuk pada kisah sukses negara Siprus dalam melakukan skrining pranikah, pada tahun 2007 tidak ada kelahiran bayi thalassaemia mayor. Upaya pengendalian resiko selanjutnya yang dapat dilakukan adalah skrining pranikah. Hal ini bertujuan untuk memastikan setiap pasangan tidak membawa sifat thalassaemia, sehingga resiko penurunan thalassaemia pada anak dapat diketahui sejak awal. Tujuan utama dari penelitan ini diantaranya:

1. Skrining pranikah merupakan bentuk upaya pencegahan thalassaemia mayor yang efektif dan efisien yang perlu diadakan di seluruh wilayah Indonesia, khususnya di wilayah dengan jumlah kasus tinggi, seperti provinsi Jawa Barat, DKI Jakarta, Jawa Tengah dan Banda Aceh.

2. Adanya skrining pranikah diharapkan dapat memberikan informasi dan pengetahuan baru kepada masyarakat, bahwa thalassemia dapat dicegah sejak awal pernikahan.

3. Memberikan informasi kepada pemerintah, bahwa penderita thalassaemia, mayoritas menggunakan layanan BPJS Kesehatan, hal ini menunjukkan bahwa biaya yang harus dikeluarkan oleh keluarga penderita perlu disubsidi, karena penderita selalu melakukan transfusi darah dalam periode tertentu. 
4. Biaya skrining yang relatif lebih murah jika dibandingkan dengan pengobatan thalassaemia mayor, dapat membantu mengurangi beban BPJS Kesehatan.

\section{Metodologi}

Objek penelitian yang pertama adalah Yayasan Thalassaemia Indonesia (YTI) sebagai pemilik data penderita thalassaemia mayor di Indonesia. Objek penelitian yang kedua adalah PT. Dua Empat Tujuh sebagai fasilitator dan mediator terhadap izin penggunaan sumber data dalam penelitian ini.

Metode penelitian yang digunakan adalah metode kuantitatif, yakni dengan menghitung jumlah penderita thalassaemia mayor di Indonesia, kemudian mengelompokan berdasarkan status pernikahan, usia penderita, golongan darah dan layanan kesehatan yang sudah digunakan. Beberapa langkah yang dilakukan dalam penelitian ini diantaranya penentuan sumber data, pembersihan data / cleansing data, normalisasi tabel penyimpanan, perancangan basis data baru yang digunakan untuk kegiatan analisis ini, dan yang terakhir adalah proses penelusuran masalah dengan teknik query / SQL.

\section{Penentuan sumber data}

Data yang digunakan dalam penelitian ini berasal dari Sistem Informasi Thalassaemia yang sudah dimiliki oleh YTI pada sistem sebelumnya, dan data skrining yang dihasilkan pada sistem baru yang dikembangkan oleh PT. Dua Empat Tujuh, dengan batasan data yang digunakan dari tahun 2010 sampai dengan 2019. Gambar 1 merupakan proses cleansing data yang dilakukan pada penelitian ini :

\section{Cleansing data dan normalisasi}

Data cleansing adalah suatu proses mendeteksi dan memperbaiki (atau menghapus) data set, tabel, dan database yang korup atau tidak akurat [6]. Yaitu merubah data thalasemia mentah agar menjadi data yang berkualitas agar dapat menghasilkan informasi yang akurat. Data yang berkualitas harus memiliki indikasi sebagai berikut:

1. Validitas : Tingkat kepatuhan terhadap aturan atau batasan bisnis yang ditetapkan

2. Akurasi : Tingkat kesesuaian ukuran dengan standar atau nilai sebenarnya

3. Kelengkapan : Sejauh mana semua tindakan yang diperlukan diketahui

4. Konsistensi : Sejauh mana seperangkat tindakan setara di seluruh sistem

5. Keseragaman : Tingkat pengukuran data yang ditetapkan dengan menggunakan satuan ukuran yang sama di semua sistem designations.

Normalisasi merupakan proses pengelompokan elemen data menjadi tabel yang menunjukkan entitas sekaligus relasinya [7]. Normalisasi dilakukan untuk mencegah terjadinya anomali insert, anomali delete, anomali update. Pada database thalasemia yang baru.

\section{Query}

Penelusuran dilakukan dengan menggunakan teknik query yang merupakan perintah untuk mengakses dan menampilkan data pada database [8]. Penelusuran ini diharapkan mendapatkan informasi mengenai perkembangan thalassaemia mayor di Indonesia dalam kurun waktu 10 tahun (2010-2019), mengetahui persentase penderita thalassaemia mayor, minor dan normal dalam kurun waktu 10 tahun (2010-2019), mengetahui persentase penderita thalassaemia mayor berdasarkan status pernikahan dalam kurun waktu 10 tahun (2010-2019), 


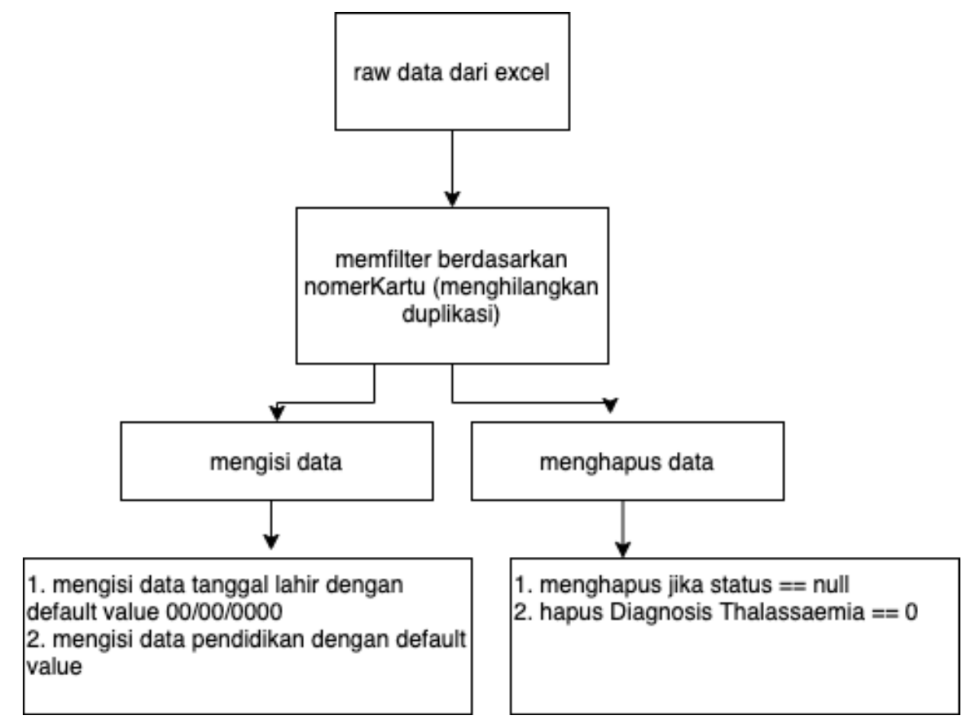

Gambar 1 Proses cleansing data

mengetahui persentase penderita thalassaemia mayor berdasarkan usia penderita dalam kurun waktu 10 tahun (2010-2019), dan mengetahui jumlah penderita thalassaemia mayor berdasarkan golongan darah dalam kurun waktu 10 tahun (2010-2019). Menghitung persentase penggunaan asuransi BPJS oleh penderita thalassaemia mayor dalam kurun waktu 10 tahun (2010-2019).

\section{Hasil dan pembahasan}

Proses cleansing data, penghapusan terhadap atribut yang tidak digunakan dalam penelitian ini karena terdapat value yang kosong, seperti, no telepon, dan pekerjaan. Atribut tersebut dihilangkan karena tidak akan mempengaruhi terhadap penelusuran yang dilakukan. Memberikan nilai default terhadap atribut yang masih memiliki nilai kosong, seperti atribut jenis jaminan kesehatan akan diisi dengan value lain-lain apabila value kosong. Hal ini dilakukan untuk menghitung persentase penggunaan asuransi BPJS Kesehatan dibandingkan asuransi lain atau kondisi lain, misalnya saja penderita belum memiliki asuransi kesehatan atau sudah memiliki asuransi selain BPJS. Memperbaiki format data untuk atribut lama deteksi menjadi tahun terdeksi sebagai penderita thalassaemia mayor. Hal ini dilakukan untuk menghitung jumlah penderita thalassaemia mayor setiap tahunnya, karena pada sistem sebelumnya hanya dihasilkan data lama terdeteksi dibandingkan dengan tahun sekarang (2019).

Normalisasi terhadap tabel penyimpanan, pada table user dan screening. Proses normalisasi pada kedua tabel tersebut perlu dilakukan karena tabel-tabel tersebut akan digunakan dalam analisis dan penelusuran masalah. Sehingga tidak ditemukan lagi redundansi data yang akan mempengaruhi pada jumlah data yang ditampilkan. Pembuatan basis data baru untuk menyimpan data-data yang sudah siap untuk dianalisis. Pembuatan basis data baru ini bertujuan untuk memudahkan dalam pembacaan jumlah tabel yang digunakan dalam analisis ini.

Penelusuran masalah dalam penelitian ini menggunakan bahasa query, dikarenakan data disimpan di dalam suatu basis data MySQL. Tujuan dari penelusuran ini untuk menggali informasi berdasarkan kriteria-kriteria yang sudah ditentukan sebelumnya. Kriteria yang 
sudah ditentukan diantaranya, menghitung jumlah penderita thalassameia mayor dalam kurun waktu 10 tahun (2009-2010), menghitung nilai persentase thalassaemia mayor, thalassaemia karier dan normal dalam kurun waktu 10 tahun (2010-2019), menghitung persentase jumlah penderita thalassaemia berdasarkan status pernikahan dalam kurun waktu 10 tahun (20102019), menghitung jumlah penderita thalassaemia mayor berdasarkan usia penderita dalam kurun waktu 10 tahun (2010-2019), dan menghitung persentase penggunaan asuransi BPJS Kesehetan oleh penderita thalassaemia dalam kurun waktu 10 tahun (2010-2019).

\section{Hasil penelusuran 1}

Penelusuran tahap pertama, bertujuan untuk mengetahui perkembangan thalassaemia mayor dalam kurun waktu 10 tahun (2010-2019) [2]. Dari Gambar 2 berikut ini menunjukkan bahwa pada tahun 2011 jumlah thalassaemia mayor tertinggi, selama kurun waktu 10 tahun di angka 499 jiwa. Pada 2011 hingga 2018 mengalami penurunan, dan mengalami peningkatan di tahun 2019.

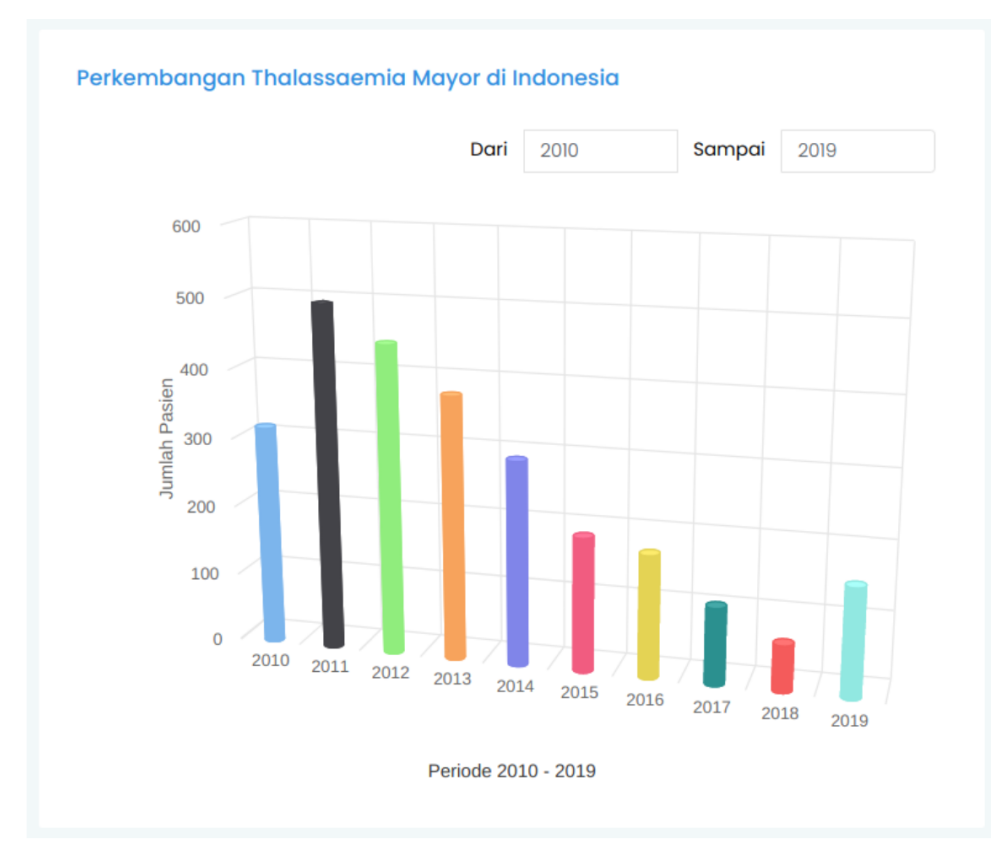

Gambar 2 Grafik Pertumbuhan Thalasemia 2010-2019

\section{Hasil penelusuran 2}

Penelusuran tahap kedua, menggali informasi perkembangan dan penyebaran thalassaemia mayor di berbagai wilayah di Indonesia pada tahun 2010-2019, hal ini dilakukan untuk mengukur seberapa besar kasus thalassaemia dari tiap-tiap daerah di Indonesia [2]. Pada tahun 2010 di wilayah provinsi Jawa Barat menduduki peringkat pertama dalam jumlah kasus thalassaemia mayor sebesar 137 jiwa. Pada tahun 2011 provinsi Jawa Barat masih menjadi peringkat pertama dengan jumlah kasus 185 jiwa. Bahkan pada tahun-tahun berikutnya provinsi Jawa Barat masih menjadi peringkat pertama dalam jumlah kasus thalassaemia mayor. Baru pada tahun 2019, posisi Jawa Barat digantikan oleh provinsi Banda Aceh dengan jumlah kasus 133 jiwa. Dari penelusuran dan informasi yang dihasilkan diharapkan 
dapat digunakan untuk mengukur atau memproyeksikan upaya yang dilakukan oleh tiap-tiap daerah dalam penanggulangan faktor resiko penurunan thalassaemia pada anak.

\section{Hasil penelusuran 3}

Penelusuran tahap ketiga, menghitung persentase thalassaemia mayor, minor dan normal di Indonesia pada tahun 2010-2019, guna mengukur kegiatan skrining perlu dilakukan atau tidak. Dari penelusuran yang sudah dilakukan bahwa pada tahun 2010-2018 persentase thalassaemia mayor adalah 100\%. Kemudian pada tahun 2019 persentase thalassaemia mayor adalah 99\%. Dari informasi yang dihasilkan dalam penelusuran ini, menunjukan bahwa kasus thalassaemia mayor masih sangat tinggi, sebagai bentuk upaya pencegahan penurunan pada anak, maka kegiatan skrining perlu dilakukan $[9 ; 10]$.

\section{Hasil penelusuran 4}

Penelusuran pada tahap keempat, menghitung persentase thalassaemia mayor berdasarkan status pernikahan per tahunnya, dimulai dari tahun 2010 sampai 2019. Penelusuran ini dilakukan karena persentase thalassaemia mayor pada penelusuran ketiga masih sangat tinggi, sehingga perlu dianalisa lebih detail lagi mengenai jumlah penderita dengan status belum menikah apakah memiliki persentase yang tinggi atau tidak. Dari hasil penelusuran pada 2010-2019 penderita thalassaemia mayor dengan status belum menikah memiliki persentase diatas $97 \%$, sehingga kegiatan skrining pranikah perlu dilakukan[2].

\section{Hasil penelusuran 5}

Pada penelusuran kelima, menghitung persentase thalassaemia mayor berdasarkan usia penderita pertahunnya, mulai dari tahun 2010-2019. Hal ini dilakukan karena pada penelusuran sebelumnya untuk status belum menikah masih sangat tinggi, sehingga penelusuran ini perlu dilakukan untuk mendapatkan informasi persentase usia matang untuk menikah (20-30 tahun) apakah selalu muncul setiap tahunnya [2]. Dari hasil penelusuran dari tahun 2010-2019, penderita dengan usia 20-30 tahun selalu muncul. Sebagai contoh hasil penelusuran yang sudah dilakukan dapat dilihat pada Gambar 3, pada tahun 2019 persentase usia matang (20-30 tahun) penderita thalassaemia mayor adalah $12 \%$.

Dari hasil penelusuran 2, 3, 4 dan 5 dapat diambil kesimpulan sementara bahwa kegiatan skrining pranikah perlu dilakukan di wilayah-wilayah yang memiliki jumlah kasus tinggi, sehingga kasus kelahiran thalassaemia mayor dapat dicegah dan dikendalikan.

\section{Hasil penelusuran 6}

Pada penelusuran keenam, menggali informasi penderita thalassaemia mayor yang sudah menggunakan asuransi BPJS, hal ini dilakukan untuk memastikan apakah semua penderita thalassaemia mayor sudah mendapatkan pelayanan kesehatan khususnya asuransi kesehatan, sesuai Peraturan Menteri Kesehatan Republik Indonesia Nomor 1109/Menkes/Per/Vi/2011 Tentang Petunjuk Teknis Jaminan Pelayanan Pengobatan thalassaemia butir yang b yang berbunyi bahwa program Jamkesmas telah mengalami perluasan, termasuk di dalamnya perluasan kepesertaan berupa pemberian pelayanan kesehatan bagi penderita thalassaemia Mayor [11]. Dari penulusuran 6 dapat diambil kesimpulan bahwa penderita thalassaemia mayoritas menggunakan layanan BPJS Kesehatan, artinya biaya yang dikeluarkan oleh keluarga penderita perlu disubsidi oleh pemerintah, karena penderita selalu melakukan transfusi darah dalam periode tertentu. 

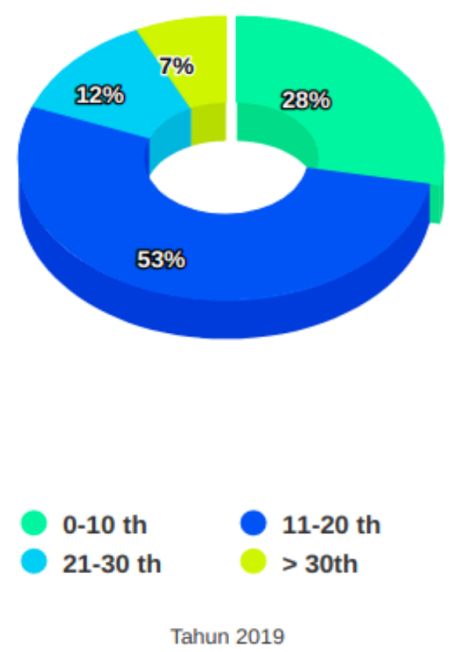

Gambar 3 Persentase thalassaemia mayor berdasarkan usia tahun 2018 dan 2019

\section{Kesimpulan}

Menekan laju pertumbuhan thalassaemia mayor di Indonesia dapat dilakukan dengan upaya skrining pranikah. Merujuk pada hasil analisis, penderita thalassaemia mayor pada usia siap menikah (20-30 tahun) masih sangat tinggi, yakni sebesar $12 \%$ pada tahun 2019. Skrining pranikah dapat dilakukan di wilayah-wilayah dengan penyebaran tinggi seperti provinsi Jawa Barat, DKI Jakarta, Jawa Tengah dan Banda Aceh, sehingga dapat mencegah penurunan thalassaemia pada anak. Tanggungan BPJS Kesehatan untuk penderita thalassaemia mayor dari tahun ke tahun akan mengalami peningkatan, karena masih ada penderita yang belum memiliki asuransi yang berpotensi untuk mendaftarkan diri sebagai peserta BPJS. Subsidi dana kesehatan khususnya penderita thalassaemia perlu dilakukan, karena mayoritas penderita menggunakan layanan BPJS Kesehatan.

\section{Pustaka}

1 P. A. Wahidiyat, T. T. Sari, L. D. Rahmartani, I. Setianingsih, S. D. Iskandar, A. M. Pratanata, I. Yapiy, M. Yosia, dan F. Tricta, "An insight into indonesian current thalassaemia care and challenges," ISBT Science Series, vol. 15, no. 3, pp. 334-341, 2020.

2 L. Rujito, Talasemia : Genetik Dasar dan Pengelolaan Terkini, 1st ed. Universitas Jenderal Soedirman, 102019.

3 Kemenkes, "Talasemia, penyakit berbiaya tinggi ke-5 di indonesia," Mei 2019. [Online]. Available: https://www.kemkes.go.id/article/view/19052100001/ -talasemia-penyakit-berbiaya-tinggi-ke-5-di-indonesia.html

4 P. A. Wahidiyat, T. T. Sari, L. D. Rahmartani, I. Setianingsih, S. D. Iskandar, dan A. M. a. Pratanata, "Managing thalassemia in indonesia: A work in progress," Vox Sanguinis, vol. 114, no. S2, 2019. [Online]. Available: https://onlinelibrary.wiley.com/doi/abs/10.1111/vox.12847 
5 worldometers, "Worldometers, "indonesia population"," Mei 2020. [Online]. Available: https://www.worldometers.info/world-population/indonesia-population/

6 H. Müller dan J. C. Freytag, Problems, methods, and challenges in comprehensive data cleansing. Professoren des Inst. Für Informatik, 2005.

7 E. Utami dan S. Raharjo, RDBMS dengan PostgreSQL di GNU/Linux. Penerbit Andi, 2006.

8 A. Kadir, Konsep 8 Tuntunan Praktis Basis Data. Penerbit Andi, 1999.

9 Kemenkes, "Angka pembawa sifat talasemia tergolong tinggi," Mei 2019. [Online]. Available: https://www.kemkes.go.id/article/view/19052100003/ angka-pembawa-sifat-talasemia-tergolong-tinggi.html

10 - "Skrining penting untuk cegah thalassemia," Mei 2017. [Online]. Available: https://www.kemkes.go.id/article/view/17050900002/ skrining-penting-untuk-cegah-thalassemia.html

11 "Keputusan menteri kesehatan republik indonesia. "peraturan menteri kesehatan republik indonesia nomor 1109/menkes/per/vi/2011 tentang petunjuk teknis jaminan pelayanan pengobatan thalasaemia." [Online]. Available: https://persi.or.id/wp-content/uploads/ 2020/11/pmk11092011.pdf 